\title{
Christ's face revealed at Shivta: an Early Byzantine wall painting in the desert of the Holy Land
}

Emma Maayan-Fanar ${ }^{1, *}$, Ravit Linn ${ }^{2}$, Yotam Tepper ${ }^{3} \&$ Guy Bar-Oz ${ }^{3}$

A previously unknown painting of Christ's face, recently discovered at the Byzantine site of Shivta in the Negev Desert of southern Israel, represents the first pre-iconoclastic baptism-ofChrist scene to be found in the Holy Land.

Shivta was a large village dated to the Byzantine period, which, at its fifth- to sixth-century $\mathrm{AD}$ peak included three churches (Figure 1). The site declined considerably in the Early Islamic period (seventh to late ninth centuries $\mathrm{AD}$ ), and was then abandoned, until its nineteenth-century rediscovery. We examined the Shivta churches' main features to reconstruct the site's historical trajectory in the context of understanding the Byzantine collapse in the Negev Desert (Tepper et al. 2015, 2018). We documented the extant artwork depicting the transfiguration of Christ on the walls of Shivta's southern church (Linn et al. 2017; Maayan-Fanar 2017).

The northern church dates to the fifth or sixth century AD (Negev 1981; RosenthalHeginbottom 1982; Segal 1985; Margalit 1987). A wall painting was attested within the apse of the Baptistery chamber beside the northern church (Figures 2-4). Due to poor preservation, the painting was only briefly noted in the late 1920s (Mallon 1930). Despite its fragmentary condition, it reveals a youth's face depicted on the apse's upper section (Figure 5). The figure has short curly hair, a prolonged face, large eyes and an elongated nose. The neck and upper portion are also observable. To the left of the figure, another, much larger face surrounded by a halo (Figure 4) is visible. Paint traces throughout the apse suggest that these faces were part of a wider scene, which could contain additional figures. The location of the scene-above the crucifix-shaped Baptist font-suggests its identification as the baptism of Christ. Thus, this face portrays the youthful Christ, while the face on the left is most probably of John the Baptist.

The baptism-of-Christ scene is found frequently in Early Christian and Byzantine art, providing multiple iconograpic and artistic comparisons for the Shivta scene (Jensen 2011). Following the scene's Early Christian iconographic convention, John the Baptist is clearly proportionally larger than Christ, whose painted figure is much smaller and younger. Christ's depiction as a youth corresponds to the symbolic notion of baptism as a rebirth.

1 Department of Art History, University of Haifa, Mount Carmel, Haifa 3498838, Israel

2 Conservation of Material Culture Heritage Unit, Department of Archaeology, University of Haifa, Mount Carmel, Haifa 3498838, Israel

3 Zinman Institute of Archaeology, University of Haifa, Mount Carmel, Haifa 3498838, Israel Author for correspondence (Email: efanar@univ.haifa.ac.il)

(C) Antiquity Publications Ltd, 2018 ANTIQUITY 92 364, e8 (2018): 1-5 


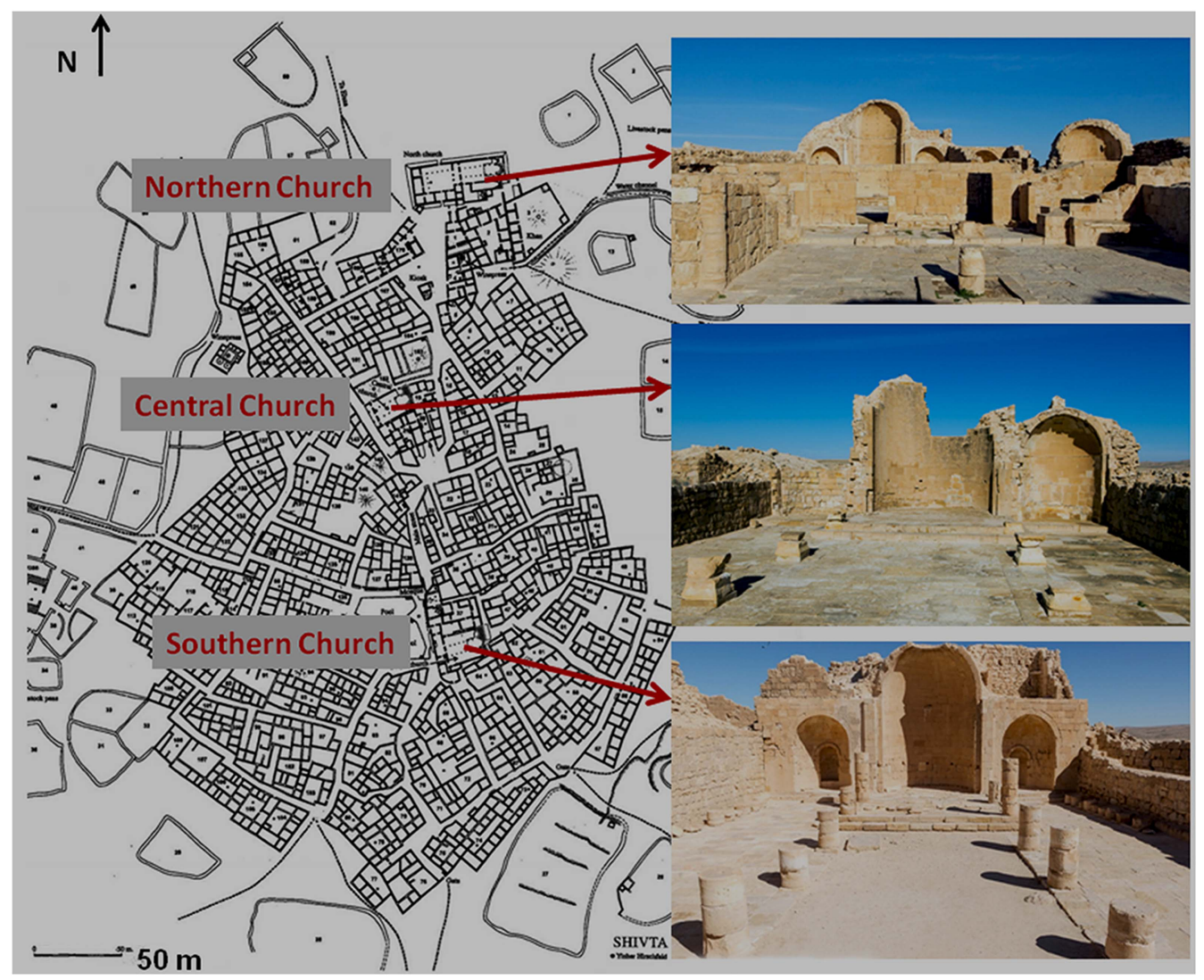

Figure 1. Plan of Shivta, with the location of its three churches shown (site plan amended from Hirschfeld 2003: fig. 3; photographs by Dror Maayan).

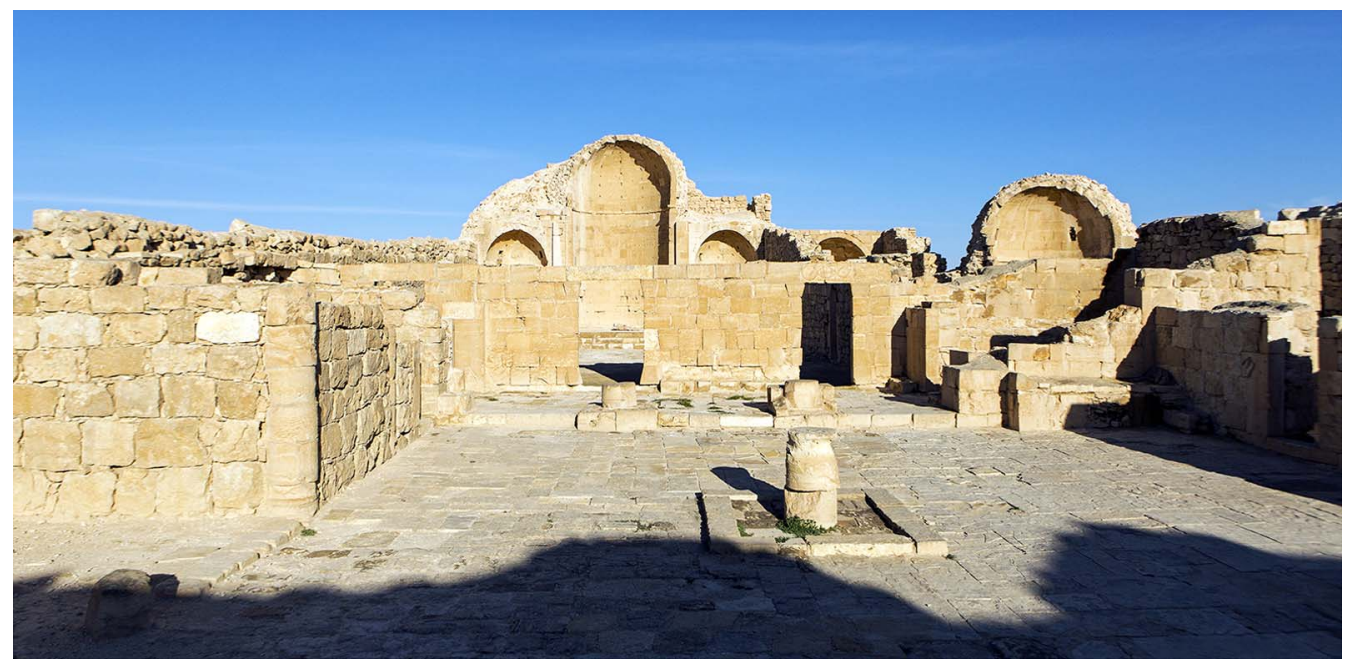

Figure 2. The Northern Church, Shivta (photograph by Dror Maayan).

(C) Antiquity Publications Ltd, 2018 


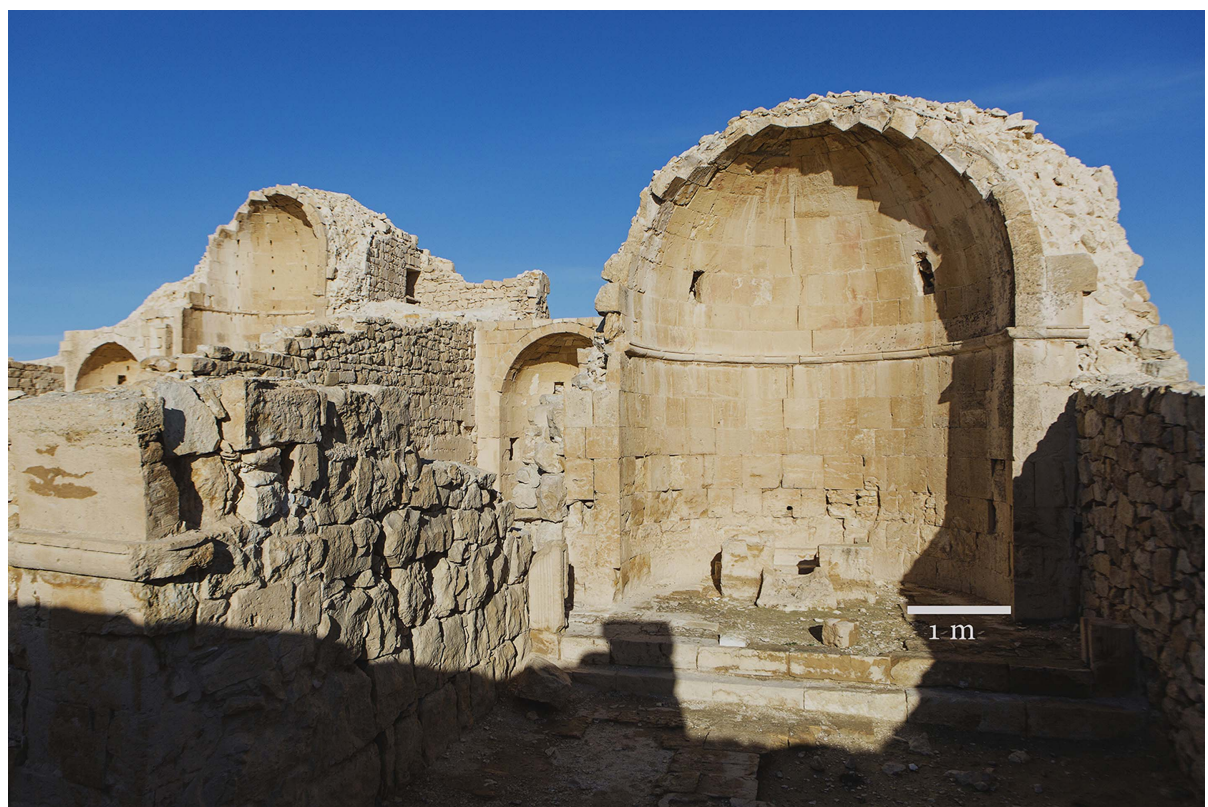

Figure 3. The Baptistery chamber beside the Northern Church, Shivta (photograph by Dror Maayan).

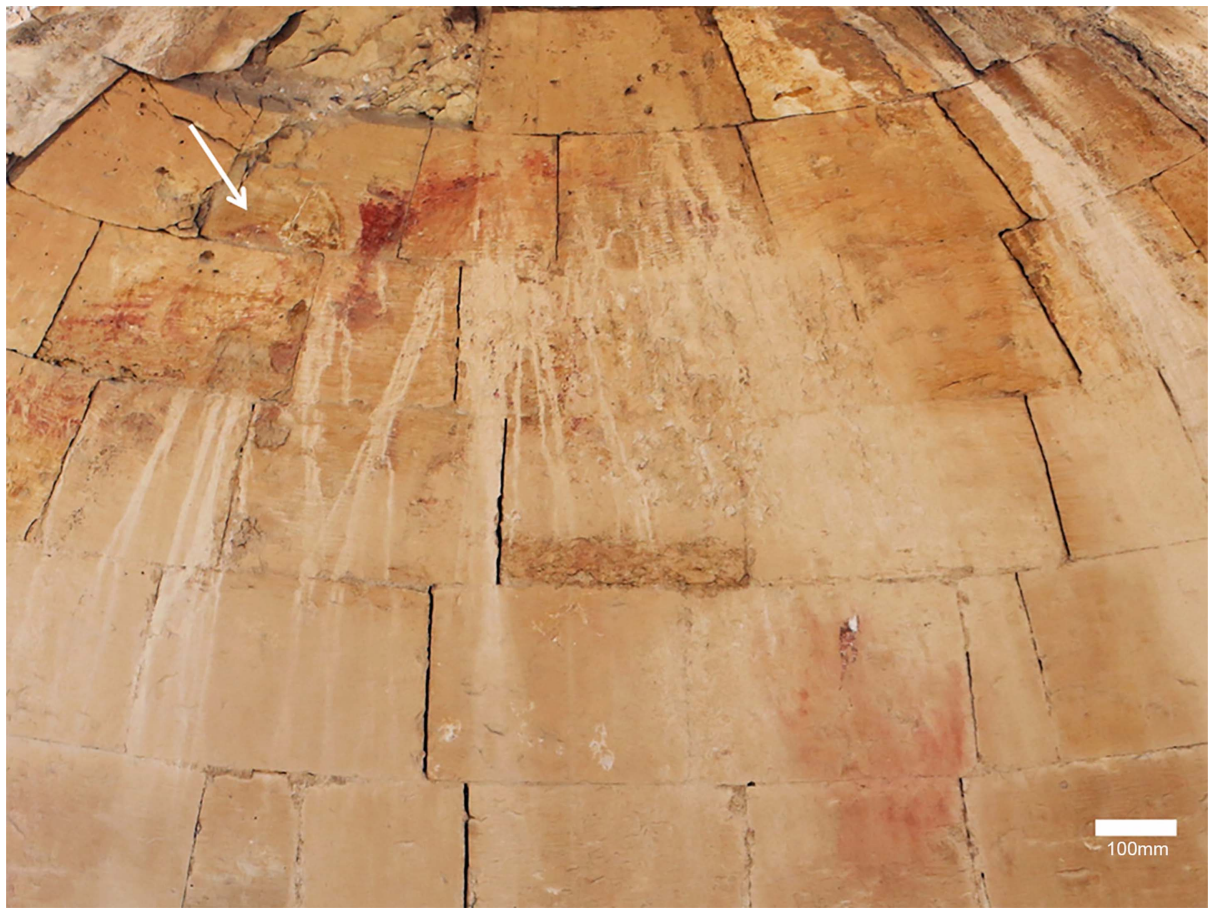

Figure 4. Remnants of the baptism-of-Christ scene (indicated by white arrow) on the apse of the Baptistery chamber (photograph by Dror Maayan).

(C) Antiquity Publications Ltd, 2018 


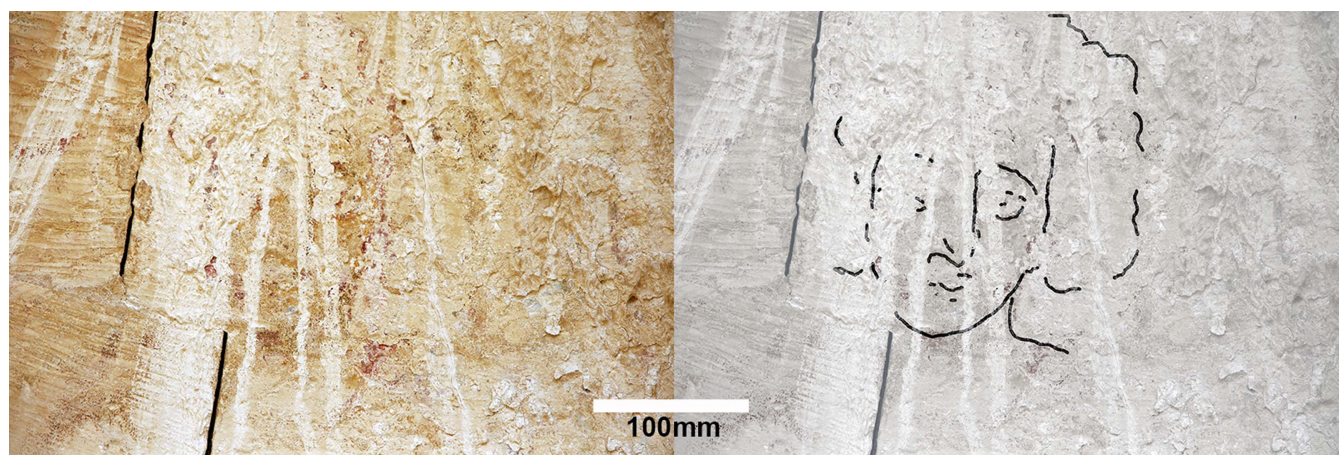

Figure 5. The face of Christ with proposed reconstruction (photograph by Dror Maayan).

Christ's face in this painting is an important discovery in itself. It belongs to the iconographic scheme of a short-haired Christ, which was especially widespread in Egypt and Syro-Palestine, but gone from later Byzantine art. Early sixth-century texts include polemics concerning the authenticity of Christ's visual appearance, including his hairstyle (Bacci 2014). Based on iconography, we estimate that this scene was also painted in the sixth century AD.

Additional details of the painting at the scene's centre, surrounding Christ's face, are hidden beneath an accumulation of dust and mud, which protects the underlying paint layers from further deterioration. We aim to continue studying the painting to ensure its future preservation. As well as gaining a better understanding of the scene's style and iconography, we will document the remaining paint in the apse, study the materials and techniques used, and determine the conditions and measures required to preserve such an important and sensitive Byzantine relict.

The discovery of this painting is extremely important. Thus far, it is the only in situ baptism-of-Christ scene to date confidently to the pre-iconoclastic Holy Land. Therefore, it can illuminate Byzantine Shivta's Christian community and Early Christian art across the region.

\section{Acknowledgements}

This study was conducted at the Shivta National Park and at a UNESCO World Heritage site, under the licence of the Israel Antiquities Authority (G-87/2015, G-4/2016) and with the permission of the Israel Nature and Parks Authority (6002/16). We are grateful for the assistance of Shivta National Park manager Avi Biton and his personnel. This project has received funding from the European Research Council under the EU's Horizon 2020 research and innovation programme (648427) and the Israel Science Foundation (340-14).

\section{References}

Bacci, M. 2014. The many faces of Christ. Portraying the Holy in the East and West, 300 to 1300. London: Reaktion.

Hirschfeld, Y. 2003. Social aspects of the Late Antique village of Shivta. Journal of Roman Archaeology 16: 395-408.

(C) Antiquity Publications Ltd, 2018
JENSEN, R.M. 2011. Living water images, symbols, and settings of Early Christian baptism. Leiden: Brill.

Linn, R.Y.G. Tepper \& Y.G. Bar-Oz. 2017. Visible induced luminescence reveals invisible rays shining from Christ in the Early Christian wall painting of the transfiguration in Shivta. PLoS ONE 12: e0185149. https://doi.org/10.1371/journal.pone.0185149 
MaAYan-Fanar, E. 2017. The transfiguration at Shivta: retracing Early Byzantine iconography. Zograf 41: 1-18. https://doi.org/10.2298/ZOG1741001M

Mallon, A. 1930. Le baptistère de Sbeita. Journal of the Palestine Oriental Society 10: 227-29.

Margalit, S. 1987. The North Church of Shivta: the discovery of the first church. Palestine Exploration Quarterly 119: 106-21.

Negev, A. 1981. The Greek inscriptions from the Negev. Jerusalem: Studium Biblicum Franciscanum.

Rosenthal-Heginbottom, R. 1982. Die Kirchen von Sobota und die Dreiapsidenkirchen des Nahen Ostens. Wiesbaden: Harrassowitz.
Segal, A. 1985. Shivta: a Byzantine town in the Negev Desert. Journal of the Society of Architectural Historians 44: 317-28. https://doi.org/10.2307/990111

Tepper, Y., L. Weissbord \& G. Bar-Oz. 2015. Behind sealed doors: unravelling abandonment dynamics at the Byzantine site of Shivta in the Negev Desert. Antiquity Project Gallery 89(348). Available at: https://www.antiquity.ac.uk/ projgall/bar-oz348 (accessed 20 July 2018). Tepper, Y., T. Erickson-Gini, Y. Farhi \& G. Bar-Oz. 2018. Probing the Byzantine/Early Islamic transition in the Negev: the renewed Shivta excavations, 2015-2016. Tel Aviv 45: 55-87. 